\title{
Range of plasma brain natriuretic peptide (BNP) levels in hemodialysis patients at a high risk of 1-year mortality and their relationship with the nutritional status: a retrospective cohort study in one institute
}

Etsuko Kumagai ${ }^{1} 2^{*}$, Keiko Hosohata $^{3}$, Kazuhiro Furumachi $^{1}$ and Shinji Takai $^{2}$

\begin{abstract}
Background: Brain natriuretic peptide (BNP) levels are used as a marker of heart failure, which is the leading cause of morbidity and mortality in dialysis patients. BNP levels increase as renal function declines. The range of BNP levels associated with satisfactory longevity in dialysis patients currently remains unknown.

Methods: In total, 660 patients receiving maintenance hemodialysis were enrolled. BNP levels were measured at the end of the year and in a follow-up to assess 1-year mortality between 2008 and 2012. Patients were divided into six groups according to BNP levels: $<50$ (reference), 50 to $<100,100$ to $<300,300$ to $<500,500$ to $<1000$, and $\geq 1000 \mathrm{pg} / \mathrm{mL}$. One-year mortality at each BNP level was analyzed using Cox's proportional hazards model after adjustments for confounding factors.

Results: During the follow-up period, 78 (11.8\%) deaths were recorded. After adjustments for confounding factors, such as gender, age, hemodialysis vintage, and primary disease, the risk of 1-year mortality was significantly high with BNP levels of 500 to $<1000$ (hazard ratio [HR] 3.010; 95\% confidence interval [CI] 1.065-10.729; $P=0.037$ ) and more than $1000 \mathrm{pg} / \mathrm{mL}$ (HR 5.291; 95\% Cl 2.014-18.170; $P=0.0003$ ). After adjustments for Kt $N$, the risk of 1-year mortality was also significantly high with BNP levels of 500 to $<1000$ (HR 3.045; 95\%Cl 1.065-10.929; $P=0.037$ ) and more than $1000 \mathrm{pg} / \mathrm{mL}$ (HR 5.221; 95\%Cl 1.943-18.165; $P=0.0006)$. Following further adjustments for nutritional factors, such as albumin levels, total cholesterol levels, the normalized protein catabolic rate (nPCR), body mass index (BMI), and percent creatinine generation rate (\%CGR), BNP levels of 500-1000 (HR 1.990; 95\%Cl 0.639-7.570; $P$ $=0.244)$, and more than $1000 \mathrm{pg} / \mathrm{mL}(\mathrm{HR} 2.100 ; 95 \% \mathrm{Cl} 0.663-8.105 ; P=0.213)$ were no longer risk factors.

(Continued on next page)
\end{abstract}

\footnotetext{
* Correspondence: e-kumagai@kenwakai.or.jp

'Kenwakai Hospital, 1936 Kanaenakadaira, lida, Nagano 395-0801, Japan

2Department of Innovative Medicine, Osaka Medical College, 2-7 Daigakucho, Takatsuki, Osaka 569-8686, Japan

Full list of author information is available at the end of the article
}

C C The Author(s). 2020 Open Access This article is licensed under a Creative Commons Attribution 4.0 International License, which permits use, sharing, adaptation, distribution and reproduction in any medium or format, as long as you give appropriate credit to the original author(s) and the source, provide a link to the Creative Commons licence, and indicate if changes were made. The images or other third party material in this article are included in the article's Creative Commons. licence, unless indicated otherwise in a credit line to the material. If material is not included in the article's Creative Commons licence and your intended use is not permitted by statutory regulation or exceeds the permitted use, you will need to obtain permission directly from the copyright holder. To view a copy of this licence, visit http://creativecommons.org/licenses/by/4.0/ The Creative Commons Public Domain Dedication waiver (http://creativecommons.org/publicdomain/zero/1.0/) applies to the data made available in this article, unless otherwise stated in a credit line to the data. 
(Continued from previous page)

Conclusion: In dialysis patients, a BNP level $\geq 500 \mathrm{pg} / \mathrm{mL}$ is a risk factor for 1-year mortality. The risk associated with high BNP levels is reduced by nutritional factors, which suggests a relationship between high BNP levels and the nutritional status. In conclusion, efforts are needed to maintain BNP levels at lower than $500 \mathrm{pg} / \mathrm{mL}$ and improve the nutritional status.

Keywords: Brain natriuretic peptide, Hemodialysis, Mortality, Nutritional status

\section{Background}

Brain natriuretic peptide (BNP) levels are used as a marker of heart failure [1], which is the leading cause of morbidity and mortality in hemodialysis patients. BNP levels in these patients are crucial for diagnosing and assessing the severity of heart failure and predicting future cardiovascular morbidity and mortality [2]. Plasma BNP levels increase with declines in renal function, and BNP levels are elevated in hemodialysis patients, even in the absence of heart failure. However, the normal threshold of BNP levels in hemodialysis patients currently remains unknown.

The range of BNP levels in hemodialysis patients needs to be clarified in order to ensure satisfactory longevity. Therefore, the present study investigated the relationship between plasma BNP levels and 1-year mortality in hemodialysis patients and examined the range of BNP levels associated with an improved prognosis.

\section{Methods}

In total, 660 patients receiving maintenance hemodialysis were enrolled in the present study. BNP levels were measured at the end of the year and in a follow-up to assess 1year mortality between 2008 and 2012. The hazard ratio (HR) for 1-year mortality was evaluated in six groups of patients divided according to BNP levels: $\mathrm{BNP}<50$ (control), $50 \leq \mathrm{BNP}<100,100 \leq \mathrm{BNP}<300,300 \leq \mathrm{BNP}<500,500 \leq$ $\mathrm{BNP}<1000$, and $1000 \leq \mathrm{BNP}$. Analyses were performed in four steps. In the first step, we adjusted for basal confounding factors, such as gender, age, hemodialysis vintage, and primary disease. In the second step, we adjusted for $\mathrm{Kt} / \mathrm{V}$ as a prescriptive factor. In the third step, we adjusted for nutritional factors, including serum albumin levels, total cholesterol levels, the normalized protein catabolic rate (nPCR), body mass index (BMI), and percent creatinine generation rate (\%CGR). In the fourth step, we adjusted for transthyretin (also known as prealbumin) levels.

A blood sample was obtained before the first hemodialysis session of the week. BNP levels were measured using the automatic enzyme immunoassay device AIA-600II ${ }^{\circ}$ (TOSO CORPORATION) with E-test TOSO II (BNP).

All statistical analyses were performed using JMP (ver.10). $P$ values less than 0.05 were considered to be significant.
The present study was conducted in accordance with the principles of the Declaration of Helsinki and approved by the Research Ethics Committee of Kenwakai Hospital (No. 2019008).

\section{Results}

The baseline characteristics of study participants are shown in Table 1 . Among 660 patients, 446 (67.6\%) were male. As the primary disease, 318 (48.2\%) had chronic glomerulonephritis (CGN), 255 (38.6\%) diabetic nephropathy (DN), and 87 (13.2\%) other diseases. Regarding patient characteristics related to heart disease, 578 (87.6\%) out of 660 patients were prescribed antihypertensive agents, while 147 (22.3\%) had a history of acute coronary syndrome, coronary intervention, or coronary surgery. Aortic stenosis and/ or regurgitation of more than moderate severity according to the ACC/AHA practice guidelines were noted in $40(6.2 \%)$ out of 645 patients examined by echocardiography. Mitral regurgitation of more than moderate severity and/or severe was detected in 26 (4.0\%) out of 645 patients examined by echocardiography. Heart failure with a reduced ejection fraction (< $40 \%)$ was observed in $18(2.80 \%)$ out of 641 patients examined by echocardiography. The most common hemodialysis vintage was 5-10 (29.7\%). As a hemodialysis prescription factor, $\mathrm{Kt} / \mathrm{V}$ values were the most frequently distributed between 1.4 and $<1.6$ (30.6\%). Nutritional factors were nPCR, serum albumin levels, total cholesterol levels, BMI, and \%CGR. In the analysis of targeting factors, 147 patients had a BNP level of 100 to $<200 \mathrm{pg} / \mathrm{mL}(22.3 \%)$, and 143 had a transthyretin level of 20 to $<25 \mathrm{mg} / \mathrm{dL}(21.8 \%)$. As shown in Table 2 , the mean age was $68.5 \pm 12.9$ years and mean vintage was $6.48 \pm 5.09$ years.

Table 3 shows the prognosis of study participants. During the observation period, there were 78 deaths (11.8\%). Table 4 shows the causes of death: heart failure in 19, cerebrovascular disease in 13 , infection in 11 , cachexia/uremia in 10 , sudden death in 6 , malignant tumors in 5 , gastrointestinal disease in 5 , and myocardial infarction in 4 . Table 5 shows HR for 1-year mortality after adjustments for confounding factors. DN as the primary disease was a significantly higher risk factor (HR 2.11; 95\%CI $1.31-3.45 ; P=0.0018)$ than CGN. Kt/V 
Table 1 Background characteristics of the study participants

\begin{tabular}{|c|c|c|c|c|c|c|c|c|c|c|}
\hline \multicolumn{11}{|l|}{ Basal factors } \\
\hline Gender & male & female & total & & & & & & & \\
\hline Number & 446 & 214 & 660 & & & & & & & \\
\hline$\%$ & 67.6 & 32.4 & 100 & & & & & & & \\
\hline Age (year) & $0 \sim$ & $30 \sim$ & $45 \sim$ & $60 \sim$ & $75 \sim$ & total & & & & \\
\hline Number & 6 & 24 & 115 & 285 & 230 & 660 & & & & \\
\hline$\%$ & 1 & 3.6 & 17.4 & 43.2 & 34.8 & 100 & & & & \\
\hline Primary disease & CGN & DM & others & total & & & & & & \\
\hline Number & 318 & 255 & 87 & 660 & & & & & & \\
\hline$\%$ & 48.2 & 38.6 & 13.2 & 100 & & & & & & \\
\hline Hemodialysis vintage & $<2$ & $2 \sim$ & $5 \sim$ & $10 \sim$ & $15 \sim$ & $20 \sim$ & $25 \sim$ & $\geq \mathbf{3 0}$ & total & \\
\hline Number & 136 & 186 & 196 & 91 & 39 & 10 & 2 & 0 & 660 & \\
\hline$\%$ & 20.6 & 28.2 & 29.7 & 13.8 & 5.9 & 1.5 & 0.3 & 0 & 100 & \\
\hline \multicolumn{11}{|l|}{ Hemodialysis prescription factor } \\
\hline $\mathrm{Kt} / \mathrm{V}$ & $<0.8$ & $0.8 \sim$ & $1.0 \sim$ & $1.2 \sim$ & $1.4 \sim$ & 1.6 & $1.8 \sim$ & $\geq \mathbf{2 . 0}$ & total & \\
\hline Number & 13 & 20 & 47 & 110 & 202 & 152 & 75 & 41 & 660 & \\
\hline$\%$ & 2 & 3 & 7.1 & 16.7 & 30.6 & 23 & 11.4 & 6.2 & 100 & \\
\hline \multicolumn{11}{|l|}{ Nutrition factors } \\
\hline nPCR (g/kg/day) & $<0.5$ & $0.5 \sim$ & $0.7 \sim$ & $0.9 \sim$ & $1.1 \sim$ & $\geq 1.3$ & total & & & \\
\hline Number & 21 & 175 & 320 & 124 & 17 & 2 & 660 & & & \\
\hline$\%$ & 3.2 & 26.6 & 48.5 & 18.8 & 2.6 & 0.3 & 100 & & & \\
\hline Albumin (g/dl) & $<3.0$ & $3.0 \sim$ & 3.5 & 4.0 & $\geq 4.5$ & total & & & & \\
\hline Number & 49 & 235 & 306 & 69 & 1 & 600 & & & & \\
\hline$\%$ & 7.4 & 35.6 & 46.4 & 10.5 & 0.1 & 100 & & & & \\
\hline BMI $\left(\mathrm{kg} / \mathrm{m}^{2}\right)$ & $<16$ & $16 \sim$ & $18 \sim$ & $20 \sim$ & $22 \sim$ & $24 \sim$ & $26 \sim$ & $\geq \mathbf{2 8}$ & total & \\
\hline Number & 5 & 32 & 120 & 186 & 156 & 93 & 31 & 36 & 660 & \\
\hline$\%$ & 0.7 & 4.9 & 18.2 & 28.2 & 23.7 & 14.1 & 4.7 & 5.5 & 100 & \\
\hline Total cholesterol (mg/dl) & $<80$ & $80 \sim$ & $120 \sim$ & $160 \sim$ & $200 \sim$ & $\leq \mathbf{2 4 0}$ & total & & & \\
\hline Number & 0 & 68 & 283 & 193 & 31 & 1 & 576 & & & \\
\hline$\%$ & 0 & 11.8 & 49.1 & 33.5 & 5.4 & 0.2 & 100 & & & \\
\hline \%CGR (\%) & $<60$ & $60 \sim$ & $70 \sim$ & $80 \sim$ & $90 \sim$ & $100 \sim$ & $110 \sim$ & $120 \sim$ & $\geq 130$ & total \\
\hline Number & 66 & 48 & 78 & 95 & 110 & 115 & 71 & 38 & 35 & 656 \\
\hline$\%$ & 10.1 & 7.3 & 11.9 & 14.5 & 16.8 & 17.5 & 10.8 & 5.8 & 5.3 & 100 \\
\hline \multicolumn{11}{|l|}{ Analysis targeting factors } \\
\hline BNP (pg/ml) & $<50$ & $50 \sim$ & $100 \sim$ & $200 \sim$ & $300 \sim$ & $500 \sim$ & $\geq 1000$ & total & & \\
\hline Number & 97 & 99 & 147 & 62 & 79 & 92 & 84 & 660 & & \\
\hline$\%$ & 14.7 & 15 & 22.3 & 9.4 & 12 & 13.9 & 12.7 & 100 & & \\
\hline Transthyretin (mg/dl) & $<15$ & $15-20$ & $20-25$ & $25-30$ & $30-35$ & $35-40$ & $\geq \mathbf{4 0}$ & total & & \\
\hline Number & 32 & 60 & 143 & 141 & 130 & 92 & 59 & 657 & & \\
\hline$\%$ & 4.9 & 9.1 & 21.8 & 21.4 & 19.8 & 14 & 9 & 100 & & \\
\hline
\end{tabular}

values of 1.0 to $<1.2$ were a significantly higher risk factor than 1.2 to $<1.4$ (HR 2.42; 95\%CI 1.12-5.18; $P=0.02)$. NPCR values of 0.5 to $<0.7$ were a significantly higher risk factor than 0.7 to $<0.9$ (HR 2.07; 95\%CI 1.26-3.42; $P=0.0039$ ). Serum albumin levels of 3.0 to $<3.5 \mathrm{~g} / \mathrm{dL}$ were a significantly higher risk factor ( $\mathrm{HR} 3.25$; $95 \% \mathrm{CI}$ $1.87-5.88 ; P<0.0001)$ than 3.5 to $<4.0 \mathrm{~g} / \mathrm{dL}$. \%CGR of $60-70 \%$ was a significantly higher risk factor than 90 to $<100 \%$ (HR 2.75; 95\%CI 1.11-9.92; $P<0.030$ ). Transthyretin levels of 15 to $<20 \mathrm{mg} / \mathrm{dL}$ were a significantly higher 
Table 2 Mean values of factors in study participants

\begin{tabular}{lll}
\hline Factor & Number & Mean \pm SD \\
\hline Age & 660 & $68.5 \pm 12.9$ \\
Hemodialysis vintage (year) & 660 & $6.48 \pm 5.09$ \\
$\mathrm{Kt} / \mathrm{n}$ & 660 & $1.533 \pm 0.343$ \\
$\mathrm{nPCR}(\mathrm{g} / \mathrm{kg} /$ day) & 659 & $0.782 \pm 0.157$ \\
Albumin (g/dl) & 660 & $3.49 \pm 0.412$ \\
BMl $\left(\mathrm{kg} / \mathrm{m}^{2}\right)$ & 656 & $22.21 \pm 3.06$ \\
Total cholesterol (mg/dl) & 576 & $153.04 \pm 29.14$ \\
$\% C G R(\%)$ & 656 & $92.1 \pm 24.93$ \\
BNP $(\mathrm{pg} / \mathrm{mL})$ & 660 & $480.02 \pm 732.01$ \\
\hline
\end{tabular}

$B M I$ body mass index, $B N P$ brain natriuretic peptide, $n P C R$ normalized protein catabolic rate, \%CGR percent creatinine generation rate

risk factor than 20 to $<25 \mathrm{mg} / \mathrm{dL}$ (HR 3.86; 95\%CI 1.92$8.00 ; P=0.0002$ ).

Figure 1 shows the results obtained in the Kaplan-Meier survival analysis of BNP levels. The 1-year survival rate was significantly low at a BNP level $>300 \mathrm{pg} / \mathrm{mL}$. Figure 2 shows the estimated cubic spline transformation of the relationship between BNP levels and HR for 1-year mortality adjusted for age, gender, dialysis vintage, and primary diseases. BNP levels in hemodialysis patients correlated with 1 -year mortality. Figure 3 shows a receiver operating characteristic (ROC) curve of the relationship between BNP levels and 1-year mortality. The area under the curve was 0.69 , and the cut-off value was $299.2 \mathrm{pg} / \mathrm{mL}$. Table 6 shows HR for 1-year mortality at each BNP level relative to that less than $50 \mathrm{pg} / \mathrm{mL}$. After adjustments for basal confounding factors (gender, age, primary disease, and hemodialysis vintage) (model 1), comparisons with the reference group revealed that BNP levels of 500 to $<1000$ $\mathrm{pg} / \mathrm{mL}$ were a significantly high-risk factor (HR 3.01; 95\%CI 1.07-10.73; $P<0.037$ ), as were those higher than $1000 \mathrm{pg} / \mathrm{mL}$ (HR 5.29; 95\%CI 2.01-18.17; $P<0.0003$ ). After further adjustments for Kt/V values (model 2), similar results were obtained to those in model 1. A BNP level higher than $500 \mathrm{pg} / \mathrm{mL}$ was significantly high. After further adjustments for five nutritional factors (nPCR, serum albumin levels, BMI, total cholesterol levels, and \%CGR) (model 3), BNP levels higher than $500 \mathrm{pg} / \mathrm{mL}$ were not significant. Table 7 also shows HR for 1 -year mortality at each BNP level. Models 1 and 2 were the same as those in Table 6, whereas model 4 showed HR further adjusted for transthyretin. BNP levels higher than $500 \mathrm{pg} / \mathrm{mL}$ were also not significant.

Table 3 Prognosis of study participants

\begin{tabular}{lll}
\hline Prognosis & Number & $\%$ \\
\hline Survival & 582 & 88.2 \\
Death & 78 & 11.8 \\
Total & 660 & 100 \\
\hline
\end{tabular}

Table 4 Causes of death

\begin{tabular}{lll}
\hline & Number & $\%$ \\
\hline Heart failure & 19 & 24.3 \\
Cerebrovascular disease & 13 & 16.7 \\
Infection & 11 & 14.1 \\
Cachexia/uremia & 10 & 12.8 \\
Sudden death & 6 & 7.7 \\
Malignant tumor & 5 & 6.4 \\
Gastrointestinal disease & 5 & 6.4 \\
Myocardial infarction & 4 & 5.1 \\
Others & 5 & 6.4 \\
Total & 78 & 100
\end{tabular}

Table 8 shows correlation coefficients and $P$ values for BNP and each parameter. BNP levels correlated with age, BMI, albumin levels, total cholesterol levels, $\mathrm{Kt} / \mathrm{V}$, nPCR, \%CGR, and transthyretin levels. BNP levels showed the strongest correlation with transthyretin levels.

\section{Discussion}

The Japanese Society for Dialysis Treatment (JSDT) investigated several indices related to 1 -year mortality in patients after adjustments for basal confounding factors, including gender, age, hemodialysis vintage, and primary disease; dialysis prescription factors, such as $\mathrm{Kt} / \mathrm{V}$; and nutritional factors, including nPCR, albumin levels, total cholesterol levels, BMI, and \%CGR [3]. BNP levels were not included in these indices. In the present study, we used the JSDT method to analyze HR for 1-year mortality at different BNP levels. We concluded that a BNP level higher than $500 \mathrm{pg} / \mathrm{mL}$ is a significantly high-risk factor for 1-year mortality.

The present study confirmed previous findings showing that BNP levels are a predictor of mortality in hemodialysis patients [4-6]. Naganuma et al. reported that a BNP level less than $200 \mathrm{pg} / \mathrm{mL}$ was associated with a good prognosis after a 3-year follow-up [7], whereas Biasioli et al. showed that a BNP level less than $335 \mathrm{pg} / \mathrm{mL}$ was associated with a good prognosis after a 28-month follow-up [8]. Zoccali et al. identified a BNP level higher than $125 \mathrm{pg} / \mathrm{mL}$ as a significantly high-risk factor after a 26-month follow-up $[9,10]$. Our follow-up period of 1 year was the shortest, while the number of factors used for adjustments was the largest. A shorter follow-up period is suitable for evaluating BNP levels as a tool for risk stratification and treatment guidance. BNP levels need to be maintained at lower than $500 \mathrm{pg} /$ $\mathrm{mL}$ as a daily management goal. 
Table 5 Cox's proportional hazard ratio of prognostic correcting factors

\begin{tabular}{llll}
\hline factor & $\begin{array}{l}\text { Hazard } \\
\text { ratio }\end{array}$ & $95 \% \mathrm{Cl}$ & p value \\
\cline { 1 - 2 } & lower upper & \\
\hline
\end{tabular}

Basal correcting factors

\section{Gender}

male (reference) 1

$\begin{array}{lllll}\text { female } & 0.8071195 & 0.482928 & 1.301835 & 0.3874\end{array}$

\section{Age}

$\begin{array}{lllll}\text { per year } & 1.080624 & 1.056946 & 1.105951 & 0.925391\end{array}$

Hemodialysis vintage(year)

$$
<2
$$$$
\text { 2 }
$$

$5 \sim$ (reference)

10

15

20

25

30

\section{Primary disease}

CGN (reference)

DN

$\begin{array}{llll}2.1136519 & 1.317961 & 3.452752 & 0.0018\end{array}$

others

0.94708560 .379865

$2.057472 \quad 0.8975$

Hemodialysis prescription factor

\section{Single pool Kt/V}

$<0.8$

0.8 to $<1.0$

$\begin{array}{llll}3.4472538 & 1.113841 & 9.013165 & 0.0336\end{array}$

1.0 to $<1.2$

$\begin{array}{lll}1.3144702 & 0.303081\end{array}$

$4.027443 \quad 0.6766$

1.2 to $<1.4$ (reference)

1.4 to $<1.6$

$\begin{array}{llll}2.4205658 & 1.123396 & 5.178495 & 0.0246\end{array}$

1.6 to $<1.8$

1.8 to $<2.0$

$2.0 \leqq$

Nutrition relating factors

\section{nPCR (g/kg/day)}

$$
<0.5
$$

0.5 to $<0.7$

$\begin{array}{llll}0.9066037 & 0.472084 & 1.805214 & 0.7733\end{array}$

0.61855940 .281182

0.41266280 .116978

$1.339853 \quad 0.2214$

1.1504720 .0935

$\begin{array}{llll}0.7575922 & 0.214755 & 2.1121 & 0.6157\end{array}$

0.7 to $<0.9$ (reference)

0.9 to $<1.1$

1.1 to $<1.3$

$1.3 \leqq$

\section{Albumin (g/dl)}

$<0.3$

3.0 to $<3.5$

3.5 to $<4.0$ (reference)

4.0 to $<4.5$

$\begin{array}{llll}0.5191474 & 0.0082335 & 1.810644 & 0.3393\end{array}$
Table 5 Cox's proportional hazard ratio of prognostic correcting

\begin{tabular}{|c|c|c|c|c|}
\hline \multirow[t]{2}{*}{ factor } & \multirow{2}{*}{$\begin{array}{l}\text { Hazard } \\
\text { ratio }\end{array}$} & \multicolumn{2}{|l|}{$95 \% \mathrm{Cl}$} & \multirow[t]{2}{*}{$p$ value } \\
\hline & & lower & upper & \\
\hline $4.5 \leqq$ & $3.22 \mathrm{E}-08$ & 0 & 35.6988 & 0.7359 \\
\hline \multicolumn{5}{|l|}{ Total cholesterol (mg/dl) } \\
\hline$<80$ & - & - & - & - \\
\hline 80 to $<120$ & 1.3127943 & 0.637005 & 2.493205 & 0.441 \\
\hline $\begin{array}{l}120 \text { to }<160 \\
\text { (reference) }\end{array}$ & 1 & & & \\
\hline 160 to $<200$ & 0.7676479 & 0.431736 & 1.321843 & 0.3451 \\
\hline 200 to $<240$ & 0.7481263 & 0.180457 & 2.071826 & 0.6148 \\
\hline $240 \leqq$ & 77.12728 & 4.101126 & 441.142 & 0.0104 \\
\hline \multicolumn{5}{|l|}{ BMI $\left(k g / m^{2}\right)$} \\
\hline$<16$ & 2.6829842 & 0.593253 & 12.33062 & 0.1361 \\
\hline 16 to $<18$ & 1.4307039 & 0.532743 & 3.250588 & 0.4465 \\
\hline 18 to $<20$ & 0.764411 & 0.380715 & 1.460268 & 0.4227 \\
\hline 20 to <22 (reference) & 1 & & & \\
\hline 22 to $<24$ & 0.7607745 & 0.405455 & 1.390405 & 0.3769 \\
\hline 24 to $<26$ & 0.6119119 & 0.258927 & 1.292297 & 0.206 \\
\hline 26 to $<28$ & 0.2169053 & 0.012157 & 1.01973 & 0.0538 \\
\hline $28 \leqq$ & 0.7508242 & 0.221565 & 1.927202 & 0.5806 \\
\hline \multicolumn{5}{|l|}{$\%$ CGR (\%) } \\
\hline$<60$ & 3.5766971 & 1.630619 & 8.3974 & 0.0014 \\
\hline 60 to $<70$ & 2.7486736 & 1.107819 & 6.919564 & 0.0297 \\
\hline 70 to $<80$ & 1.4473888 & 0.56513 & 3.706997 & 0.4341 \\
\hline 80 to $<90$ & 1.4485841 & 0.599571 & 3.593324 & 0.4081 \\
\hline 90 to $<100$ (reference) & 1 & & & \\
\hline 100 to $<110$ & 1.166507 & 0.482823 & 2.893589 & 0.7313 \\
\hline 110 to $<120$ & 0.508935 & 0.112931 & 1.705797 & 0.287 \\
\hline 120 to $<130$ & 0.6324356 & 0.096427 & 2.454098 & 0.5391 \\
\hline $130 \leqq$ & 1.059352 & 0.235067 & 3.550648 & 0.9314 \\
\hline \multicolumn{5}{|l|}{ Transthyretin (mg/dl) } \\
\hline$<15$ & 10.055064 & 4.997492 & 20.87464 & $<.0001$ \\
\hline 15 to $<20$ & 3.8640013 & 1.924016 & 8.008218 & 0.0002 \\
\hline 20 to <25 (reference) & 1 & & & \\
\hline 25 to $<30$ & 1.089919 & 0.509545 & 2.348036 & 0.823 \\
\hline 30 to $<35$ & 0.759041 & 0.313215 & 1.759291 & 0.5221 \\
\hline 35 to $<40$ & 0.350335 & 0.080339 & 1.086928 & 0.0712 \\
\hline $40 \leqq$ & $5.23 \mathrm{E}-10$ & 0 & 0.368802 & 0.0023 \\
\hline
\end{tabular}
factors (Continued)

$B M I$ body mass index, $C G N$ chronic glomerulonephritis, $D N$ diabetic nephropathy, $n P C R$ normalized protein catabolic rate, \%CGR percent creatinine generation rate

The risk associated with a BNP level $\geq 500 \mathrm{pg} / \mathrm{mL}$ was canceled after adjustments for nutritional factors. Therefore, a relationship appears to exist between high BNP levels and the nutritional status. The presence of chronic heart failure with ongoing weight loss or a low BMI is a 


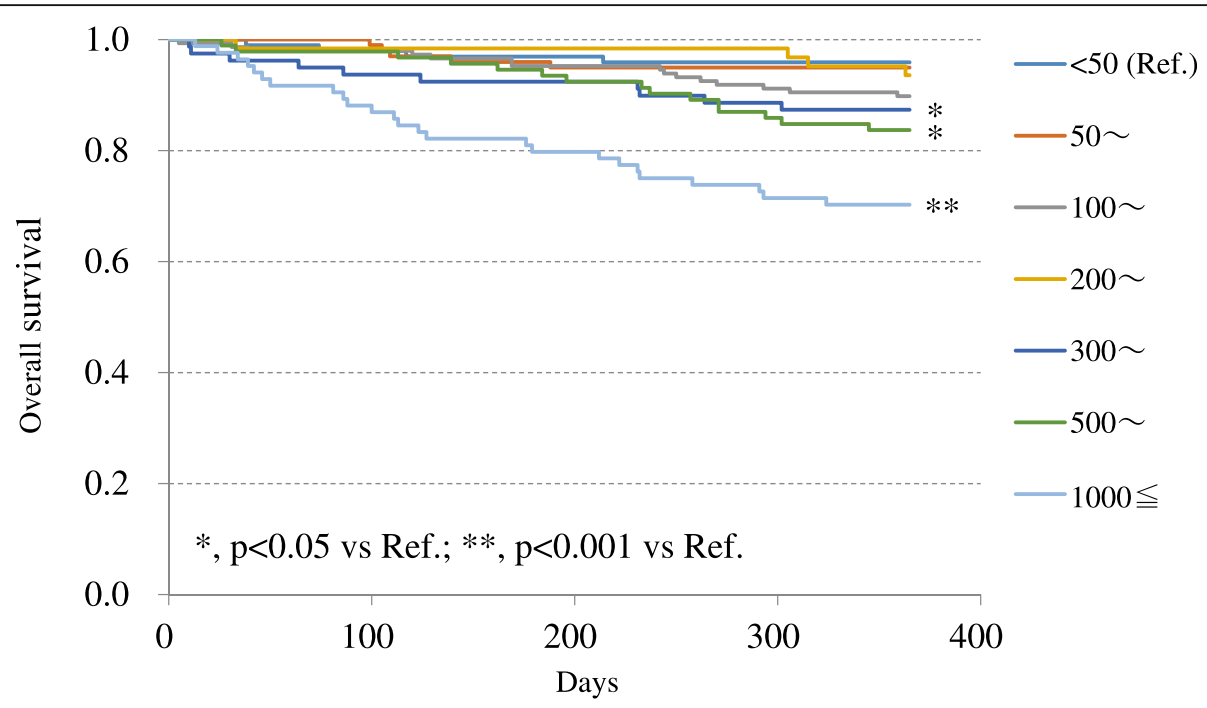

Fig. 1 Kaplan-Meier survival analysis of BNP levels. One-year survival rates were $95.5 \%$ at BNP $<50$ pg/mL, $95.0 \%$ at $50-100$ pg/mL, $90.0 \%$ at 100 $200 \mathrm{pg} / \mathrm{mL}, 93.6 \%$ at $200-300 \mathrm{pg} / \mathrm{mL}, 87.3 \%$ at $300-500 \mathrm{pg} / \mathrm{mL}, 83.7 \%$ at $500-1000 \mathrm{pg} / \mathrm{mL}$, and $70.2 \%$ at $>1000 \mathrm{pg} / \mathrm{mL}$. The 1 -year survival rate was significantly low at BNP $>300 \mathrm{pg} / \mathrm{mL}$

predictor of muscle mass loss, a decline in exercise capacity, and a poor prognosis [11]. A syndrome involving weight loss, general fatigue, fat loss, and muscle wasting with chronic disease was recently recognized as cachexia. Cachexia is a prevalent and important pathological condition associated with chronic heart failure. It reduces survival independently of the heart failure function class and ejection $[12,13]$. BNP levels play a major role in salt and water homeostasis, protecting the cardiovascular system from the effects of volume overload and cardiac comorbidities. In the bioimpedance method, BNP levels reflect individual variations in the hydration status of hemodialysis patients [14]. A value of $500 \mathrm{pg} / \mathrm{mL}$ has been used to differentiate between hemodialysis patients with or without volume overload $[15,16]$. The extracellular water content to intracellular water content ratio increases as BMI decreases. A strong negative correlation was previously reported between excess fluid mass and BMI [17]. Patients with BNP levels higher than 500 $\mathrm{pg} / \mathrm{mL}$ were overhydrated and weight loss from

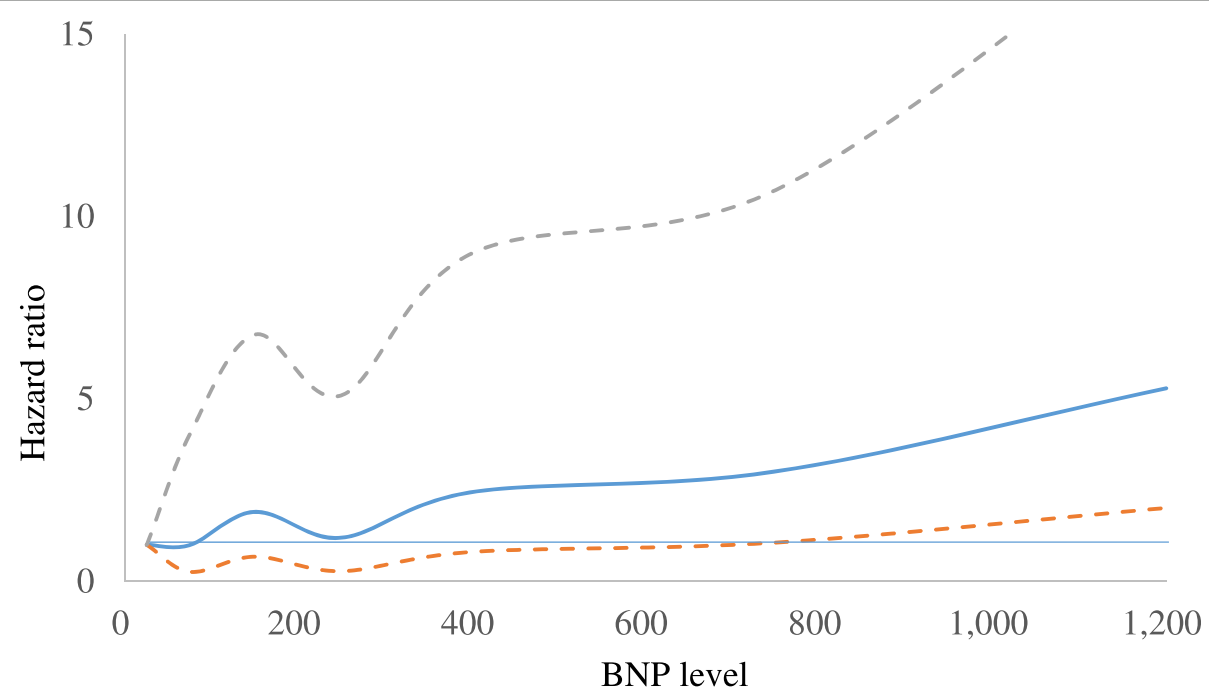

Fig. 2 Estimated cubic spline transformation of the relationship between BNP levels and the adjusted hazard ratio. The reference BNP for this plot (with HR fixed as 1.0) was $<50 \mathrm{pg} / \mathrm{mL}$. The hazard ratio of 1-year mortality was adjusted for age, gender, dialysis vintage, and primary diseases. Dotted lines are $95 \%$ confidence limits 


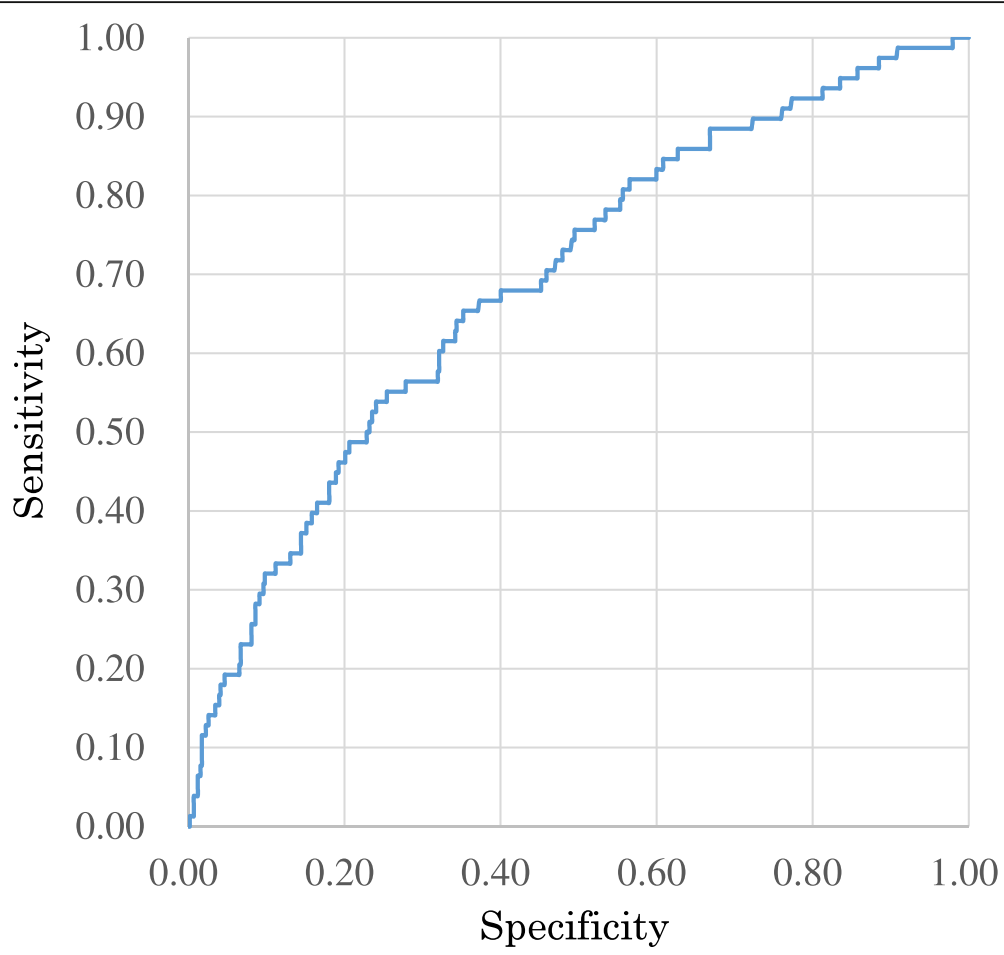

Fig. 3 Receiver operating characteristic (ROC) curve of the relationship between BNP levels and 1-year mortality. The area under the curve was 0.69 and the cut-off value was $299.2 \mathrm{pg} / \mathrm{mL}$

malnutrition resulted in additional fluid excess. On the other hand, even though BNP levels were high, good nutrition, and weight gain reduced volume overload. Chronic overhydration is an independent predictor of mortality in hemodialysis patients [18]. The risk associated with a high BNP level depends on the nutritional status. The combination of a high BNP level with a poor nutritional status needs to be treated not only by cardiological therapy, but also nutritional support. Despite the accepted importance of the influence of nutritional factors on the severity of cardiovascular disease, limited information is currently available on dietary intake and heart failure. Furthermore, existing nutritional interventions for heart failure were mostly pilot studies with small sample sizes and short follow-ups [19]. The findings of 17 randomized controlled trials indicated that education on nutritional interventions had positive effects on the clinical outcomes of patients; however, they

Table 6 HR for 1-year mortality of BNP levels adjusted for basal factors, Kt/N and nutrition factors

\begin{tabular}{|c|c|c|c|c|c|c|c|c|c|c|c|c|}
\hline \multirow[t]{3}{*}{ BNP $(\mathrm{pg} / \mathrm{ml})$} & \multicolumn{4}{|c|}{$\begin{array}{l}\text { Adjusted for basal factors } \\
\text { (model 1) }\end{array}$} & \multicolumn{4}{|c|}{$\begin{array}{l}\text { Adjusted for basal factors and Kt } N \\
\text { (model 2) }\end{array}$} & \multicolumn{4}{|c|}{$\begin{array}{l}\text { Adjusted for basal factors, Kt } / \mathrm{N} \text { and nutrition } \\
\text { factors (model } 3 \text { ) }\end{array}$} \\
\hline & \multirow[t]{2}{*}{$\mathrm{HR}$} & \multirow{2}{*}{$\begin{array}{l}\mathrm{p} \\
\text { value }\end{array}$} & \multicolumn{2}{|l|}{$95 \% \mathrm{Cl}$} & \multirow[t]{2}{*}{$\mathrm{HR}$} & \multirow{2}{*}{$\begin{array}{l}\mathrm{p} \\
\text { value }\end{array}$} & \multicolumn{2}{|l|}{$95 \% \mathrm{Cl}$} & \multirow[t]{2}{*}{$\mathrm{HR}$} & \multirow[t]{2}{*}{$p$ value } & \multicolumn{2}{|l|}{$95 \% \mathrm{Cl}$} \\
\hline & & & lower & per & & & lower & upper & & & lower & lower \\
\hline 50 (reference) & 1 & - & - & - & 1 & - & - & - & 1 & - & - & - \\
\hline 50 to $<100$ & 0.997121 & 0.9966 & 0.262147 & 4.051568 & 0.964564 & 0.9574 & 0.253041 & 3.926629 & 0.8384388 & 0.8047 & 0.205753 & 3.621547 \\
\hline 100 to $<200$ & 1.907679 & 0.2326 & 0.678499 & 6.766743 & 1.840871 & 0.2619 & 0.652984 & 6.541653 & 0.9592779 & 0.9477 & 0.292026 & 3.725938 \\
\hline 0 to $<300$ & 198396 & 7993 & 0.28121 & 5.1068 & 1.165241 & 0.8 & 0.260802 & 5.155792 & 0.8387627 & 0.8229 & 0.1700 & 4.04536 \\
\hline 300 to $<500$ & 2.446838 & 0.1157 & 0.808727 & 8.994658 & 2.5366 & 0.1026 & 0.835008 & 9.354117 & 2.5461197 & 0.133 & 0.758488 & 10.11498 \\
\hline 0 to $<1000$ & 3.009917 & 0.0369 & 1.065084 & 10.72921 & 3.044996 & 0.037 & 1.065717 & 10.92917 & 1.9907521 & 0.2444 & 0.639274 & 7.570738 \\
\hline$\geq 1000$ & 5.291238 & 0.0003 & 2.013968 & 18.17073 & 5.221112 & 0.0006 & 1.943194 & 18.16484 & 2.0999726 & 0.2136 & 0.663497 & 8.104608 \\
\hline
\end{tabular}

HR hazard ratio 
Table 7 HR for 1-year mortality of BNP levels adjusted for basal correcting factors, Kt $\mathrm{N}$ and transthyretin

\begin{tabular}{|c|c|c|c|c|c|c|c|c|c|c|c|c|}
\hline \multirow[t]{3}{*}{ BNP (pg/ml) } & \multicolumn{4}{|c|}{$\begin{array}{l}\text { Adjusted for basal factors } \\
\text { (model 1) }\end{array}$} & \multicolumn{4}{|c|}{$\begin{array}{l}\text { Adjusted for basal factors and Kt/N } \\
\text { (model 2) }\end{array}$} & \multicolumn{4}{|c|}{$\begin{array}{l}\text { Adjusted for basal factors, Kt } N \\
\text { and transthyretin (model 4) }\end{array}$} \\
\hline & \multirow[t]{2}{*}{$\mathrm{HR}$} & \multirow{2}{*}{$\begin{array}{l}\mathrm{p} \\
\text { value }\end{array}$} & \multicolumn{2}{|l|}{$95 \% \mathrm{Cl}$} & \multirow[t]{2}{*}{$\mathrm{HR}$} & \multirow{2}{*}{$\begin{array}{l}p \\
\text { value }\end{array}$} & \multicolumn{2}{|l|}{$95 \% \mathrm{Cl}$} & \multirow[t]{2}{*}{$\mathrm{HR}$} & \multirow{2}{*}{$\begin{array}{l}\mathrm{p} \\
\text { value }\end{array}$} & \multicolumn{2}{|l|}{$95 \% \mathrm{Cl}$} \\
\hline & & & lower & upper & & & lower & upper & & & lower & lower \\
\hline$<50$ (reference) & 1 & - & - & - & 1 & - & - & - & 1 & - & - & - \\
\hline 50 to $<100$ & 0.997121 & 0.9966 & 0.262147 & 4.051568 & 0.964564 & 0.9574 & 0.253041 & 3.926629 & 0.8926795 & 0.8672 & 0.233334 & 3.644237 \\
\hline 100 to $<200$ & 1.907679 & 0.2326 & 0.678499 & 6.766743 & 1.840871 & 0.2619 & 0.652984 & 6.541653 & 1.7642041 & 0.3025 & 0.619779 & 6.310716 \\
\hline 200 to $<300$ & 1.198396 & 0.7993 & 0.28121 & 5.106865 & 1.165241 & 0.8354 & 0.260802 & 5.155792 & 0.8019716 & 0.7659 & 0.178553 & 3.594217 \\
\hline 300 to $<500$ & 2.446838 & 0.1157 & 0.808727 & 8.994658 & 2.5366 & 0.1026 & 0.835008 & 9.354117 & 1.986255 & 0.2446 & 0.636523 & 7.46915 \\
\hline 500 to $<1000$ & 3.009917 & 0.0369 & 1.065084 & 10.72921 & 3.044996 & 0.037 & 1.065717 & 10.92917 & 1.7769718 & 0.3121 & 0.602509 & 6.532927 \\
\hline$\geq 1000$ & 5.291238 & 0.0003 & 2.013968 & 18.17073 & 5.221112 & 0.0006 & 1.943194 & 18.16484 & 2.710241 & 0.0653 & 0.942719 & 9.854096 \\
\hline
\end{tabular}

$H R$ hazard ratio

all involved sodium and fluid restrictions [20]. After the administration of a high-caloric $(600 \mathrm{kcal})$, high-protein $(20 \mathrm{~g})$, and oral nutritional supplement for 6 weeks to cachexic heart failure patients, significant improvements were observed in the quality of life, 6-m walking test, and tumor necrosis factor- $\alpha$ without the significant recovery of peak $\mathrm{VO}_{2}$ or the left ventricular ejection fraction; BNP was not measured in that study [21]. After the administration of $500 \mathrm{~mL} /$ day of enteral nutrition for 3 months to elderly heart failure patients, marked improvements were noted in BNP, interleukin-6, tumor necrosis factor- $\alpha$, and C-reactive protein levels [22].

After adjustments for transthyretin levels, the risk associated with BNP $\geq 500 \mathrm{pg} / \mathrm{mL}$ was no longer significant. Transthyretin is an important indicator of not only the nutritional status, but also the survival of hemodialysis patients after adjustments for age, gender, race, hemodialysis vintage, the diabetic state, and nutritional markers, including serum albumin levels [22, 23]. A recent study reported that serum transthyretin levels correlated with body fat mass [24]. The half-life of transthyretin is 23 days, which is shorter than that of serum albumin. A

Table 8 Correlation coefficients and p value for BNP and the studied parameter

\begin{tabular}{lllll}
\hline & Mean & SD & $r$ & $p$ \\
\hline Age & 68.51212 & 12.86282 & 0.222574 & $<.0001$ \\
Hemodialysis vintage (year) & 6.476169 & 5.092643 & 0.017756 & 0.6489 \\
BMI $\left(\mathrm{kg} / \mathrm{m}^{2}\right)$ & 22.2116 & 3.056318 & -0.14469 & 0.0002 \\
Albumin (g/dl) & 3.490455 & 0.4122 & -0.29155 & $<.0001$ \\
Total cholesterol (mg/dl) & 153.0382 & 29.14238 & -0.11052 & 0.0079 \\
Kt/N & 1.532889 & 0.342536 & -0.1803 & $<.0001$ \\
nPCR (g/kg/day) & 0.782168 & 0.15667 & -0.19454 & $<.0001$ \\
\%CGR (\%) & 92.01985 & 24.93402 & -0.21274 & $<.0001$ \\
Transthyretin (mg/dl) & 28.45586 & 8.384788 & -0.39012 & $<.0001$ \\
\hline BMl body mass index/ nPCR n & &
\end{tabular}

$B M I$ body mass index, $n P C R$ normalized protein catabolic rate, \%CGR percent creatinine generation rate decline in serum transthyretin levels by $10 \mathrm{~g} / \mathrm{dL}$ over 6 months is a robust predictor of increased mortality [25, 26]. The present results showed that a transthyretin level of less than $20 \mathrm{mg} / \mathrm{dL}$ was a high-risk factor. In hemodialysis patients, the combination of a BNP level $\geq$ $500 \mathrm{pg} / \mathrm{mL}$ and transthyretin level $<20 \mathrm{mg} / \mathrm{dL}$, which is a decrease of more than $10 \mathrm{mg}$, warrants urgent treatment.

\section{Conclusions}

In dialysis patients, a BNP level $\geq 500 \mathrm{pg} / \mathrm{mL}$ is a significantly high-risk factor for 1-year mortality. The risk associated with a high BNP level is canceled out after adjustments for nutritional factors. Therefore, a relationship appears to exist between high BNP levels and the nutritional status. Efforts are needed to maintain a BNP level of less than $500 \mathrm{pg} / \mathrm{mL}$ and improve nutritional factors. The risk associated with a BNP level $\geq 500 \mathrm{pg} / \mathrm{mL}$ also depends on transthyretin levels, which need to be maintained at $>20 \mathrm{mg} / \mathrm{dL}$.

\section{Abbreviations}

\%CGR: Percent creatinine generation rate; BMI: Body mass index; BNP: Brain natriuretic peptide; CGN: Chronic glomerulonephritis; DN: Diabetic nephropathy; nPCR: Normalized protein catabolic rate

\section{Acknowledgements}

Not applicable.

\section{Authors' contributions}

EK wrote the manuscript and $\mathrm{KH}$ revised it. EK contributed to the research concept and study design. KF contributed to data acquisition, the risk of bias assessment, data analysis/interpretation, and statistical analyses. ST contributed to data interpretation. EK contributed to supervision and mentorship. The authors read and approved the final manuscript.

Funding

Funding for this study was not provided by any person or institution.

\section{Availability of data and materials}

All data generated or analyzed during this study are included in this manuscript. 


\section{Ethics approval and consent to participate}

The present study was conducted in accordance with the principles of the Declaration of Helsinki and approved by the research Ethics Committee of Kenwakai Hospital (No.2019008).

\section{Consent for publication}

Not applicable.

\section{Competing interests}

The authors declare that they have no competing interests.

\section{Author details}

'Kenwakai Hospital, 1936 Kanaenakadaira, lida, Nagano 395-0801, Japan. 2Department of Innovative Medicine, Osaka Medical College, 2-7 Daigakucho, Takatsuki, Osaka 569-8686, Japan. ${ }^{3}$ Education and Research Center for Clinical Pharmacy, Osaka University of Pharmaceutical Sciences, 4-20-1 Nasahara, Takatsuki, Osaka 569-1094, Japan.

Received: 2 December 2019 Accepted: 6 July 2020

Published online: 22 July 2020

\section{References}

1. McCullough PA, Nowak RM, McCord J, Hollander JE, Herrmann HC, Steg PG, et al. B-type natriuretic peptide and clinical judgment in emergency diagnosis of heart failure: analysis from breathing not properly (BNP) multinational study. Circulation. 2002:106:416-22.

2. Hirakata H, Nitta K, Inaba M, Shoji T, Fujii H, Kobayashi S, et al. Japanese Society for Dialysis Therapy guidelines for management of cardiovascular diseases in patients on chronic hemodialysis. Therapeutic apheresis and dialysis: official peer-reviewed journal of the International Society for Apheresis, the Japanese Society for Apheresis, the Japanese Society for Dialysis Therapy. 2012;16:387-435

3. https://member.jsdt.or.jp/member/contents/cdrom/2009/FILE/zusetsu.html. Accessed 15 September 2019.

4. Wang AY, Lai KN. Use of cardiac biomarkers in end-stage renal disease. J Am Soc Nephrol. 2008;19:1643-52.

5. Teranishi M, Hirata Y, Miyashita K, Suzuki M, Ishii K, Goto A, et al. Significance of plasma brain and atrial natriuretic peptides as long-term survival predictors in hemodialysis patients-13-year follow up study. Journal of Japanese Society for Dialysis Therapy. 2006;39:1467-73.

6. Hashimoto $\mathrm{K}$, Ishiguro M, Ikutaka T, Yasue $\mathrm{Y}$, Ohkuma T, Torisawa M, et al. Can plasma BNP serve as a factor predicting cardiovascular events in hemodialyzed patients. Journal of Japanese Society for Dialysis Therapy. 1997:30:117-23.

7. Naganuma T, Sugimura K, Wada S, Yasumoto R, Sugimura T, Masuda C, et al. The prognostic role of brain natriuretic peptides in hemodialysis patients. Am J Nephrol. 2002;22:437-44.

8. Biasioli S, Zamperetti M, Borin D, Guidi G, De Fanti E, Schiavon R. Significance of plasma B-type natriuretic peptide in hemodialysis patients: blood sample timing and comorbidity burden. ASAIO J. 2007:53:587-91.

9. Mallamaci F, Zoccali C, Tripepi G, Benedetto FA, Parlongo S, Cataliotti A, et al. Diagnostic potential of cardiac natriuretic peptides in dialysis patients. Kidney Int. 2001;59:1559-66.

10. Zoccali C, Mallamaci F, Benedetto FA, Tripepi G, Parlongo S, Cataliotti A, et al. Cardiac natriuretic peptides are related to left ventricular mass and function and predict mortality in dialysis patients. J Am Soc Nephrol. 2001; 12:1508-15.

11. Evans WJ, Morley JE, Argiles J, Bales C, Baracos V, Guttridge D, et al. Cachexia: a new definition. Clin Nutr. 2008:27:793-9.

12. Anker SD, Swan JW, Volterrani M, Chua TP, Clark AL, Poole-Wilson PA, et al. The influence of muscle mass, strength, fatigability and blood flow on exercise capacity in cachectic and non-cachectic patients with chronic heart failure. Eur Heart J. 1997;18:259-69.

13. Okoshi MP, Capalbo RV, Romeiro FG, Okoshi K. Cardiac cachexia: perspectives for prevention and treatment. Arq Bras Cardiol. 2017;108:74-80.

14. Stenberg J, Melin J, Linberg M, Furuland $\mathrm{H}$. Brain natriuretic peptide reflects individual variation in hydration status in hemodialysis patients. Hemodial Int. 2019;23:402-13.

15. Lee SW, Song JH, Kim GA, Lim HJ, Kim M-J. Plasma brain natriuretic peptide concentration on assessment of hydration status in hemodialysis patient. Am J Kidney Dis. 2003;41:1257-66.
16. Tapolyai M, Faludi M, Réti V, Lengvárszky Z, Szarvas T, Fülöp T, et al. Volume estimation in dialysis patients: the concordance of brain-type natriuretic peptide measurements and bioimpedance values. Hemodial Int. 2013;17:406-12.

17. Ohashi Y, Saito A, Yamazaki K, Tai R, Matsukiyo T, Aikawa A, et al. Brain natriuretic peptide and body fluid composition in patients with chronic kidney disease: a cross-sectional study to evaluate the relationship between volume overload and malnutrition. Cardiorenal Med. 2016;6:337-46.

18. Zoccali C, Moissl U, Chazot C, Mallamaci F, Tripepi G, Arkossy O, et al. Chronic fluid overload and mortality in ESRD. J Am Soc Nephrol. 2017;28: 2491-7.

19. Kerley CP. Nutritional interventions in heart failure: challenges and opportunities: current heart failure reports. 2018;15:131-140

20. Abshire M, Xu J, Baptiste D, Almansa JR, Xu J, Cummings A, et al. Nutritional intervention in heart failure: a systematic review of the literature. J Card Fail. 2015:21:989-99.

21. Rozentryt P, von Haehling S, Lainscak M, Nowak JU, Kalantar-Zadeh K, Polonski $L$, et al. The effects of a high-caloric protein-rich oral nutritional supplement in patients with chronic heart failure and cachexia on quality of life, body composition, and inflammation markers: a randomized, doubleblind pilot study. J Cachexia Sarcopenia Muscle. 2010;1:35-42.

22. Zhou H, Qian H. Relationship between enteral nutrition and serum levels of inflammatory factors and cardiac function in elderly patients with heart failure. Clin Interv Aging. 2018;13:397-401.

23. Mittman N, Avram MM, Oo KK, Chattopadhyay J. Serum prealbumin predicts survival in hemodialysis and peritoneal dialysis: 10 years of prospective observation. Am J Kidney Dis. 2001;38:1358-64.23.

24. Chertow GM, Ackert K, Lew NL, Lazarus JM, Lowrie EG. Prealbumin is as important as albumin in the nutritional assessment of hemodialysis patients. Kidney Int. 2000;58:2512-7.

25. Matsuura S, Shirai Y, Kubo M, Nayama C, Okitsu M, Oiwa Y, et al. Body fat mass is correlated with serum transthyretin levels in maintenance hemodialysis patients. J Med Invest. 2017;64:222-7.

26. Rambod M, Kovesdy CP, Bross R, Kopple JD, Kalantar-Zadeh K. Association of serum prealbumin and its changes over time with clinical outcomes and survival in patients receiving hemodialysis. Am J Clin Nutr. 2008;88:1485-94.

\section{Publisher's Note}

Springer Nature remains neutral with regard to jurisdictional claims in published maps and institutional affiliations.

Ready to submit your research? Choose BMC and benefit from:

- fast, convenient online submission

- thorough peer review by experienced researchers in your field

- rapid publication on acceptance

- support for research data, including large and complex data types

- gold Open Access which fosters wider collaboration and increased citations

- maximum visibility for your research: over $100 \mathrm{M}$ website views per year

At BMC, research is always in progress.

Learn more biomedcentral.com/submissions 